\title{
Using online questionnaires to assess marine bio-invasions: a demonstration with recreational fishers and the Atlantic blue crab Callinectes sapidus (Rathbun, 1986) along three Mediterranean countries.
}

\author{
Cerri J. ${ }^{1} \quad$ Chiesa S. $^{2} \quad$ Bolognini L. \\ Mancinelli G. ${ }^{456}$ \\ Grati F. ${ }^{3}$ \\ Dragičević B. ${ }^{7}$ \\ Dulčić J. ${ }^{7}$ \\ Azzurro E. ${ }^{13}$ \\ ${ }^{1}$ Institute for Environmental Protection and Research (ISPRA), Livorno, Italy \\ ${ }^{2}$ Institute for Environmental Protection and Research (ISPRA), Rome, Italy \\ ${ }^{3}$ National Research Council (CNR) - Institute for Biological Resources and Marine Biotechnologies (IRBIM), Ancona, Italy \\ ${ }^{4}$ Department of Biological and Environmental Sciences and Technologies (DiSTeBA), University of Salento, Lecce, Italy \\ ${ }^{5}$ National Research Council (CNR), Institute of Biological Resources and Marine Biotechnologies (IRBIM), Lesina (FG), Italy \\ ${ }^{6}$ CoNISMa, Consorzio Nazionale Interuniversitario per le Scienze del Mare, 00196 Roma, Italy \\ ${ }^{7}$ Institute of Oceanography and Fisheries, Split, Croatia \\ May 11, 2020
}

\begin{abstract}
Marine bioinvasions require integrating monitoring tools with other complementary strategies. In this study, we collected information about the invasive Callinectes sapidus in Italy, Croatia and Montenegro, by means of online questionnaires administered to recreational fishers $(n=797)$. Our records matched the current distribution of the species: $\boldsymbol{C}$. sapidus resulted far more common in the Adriatic, than in the Tyrrhenian sector. Most respondents rated the species as 'occasional' or 'rare'. Moreover, the more $C$. sapidus was considered to be abundant, the more fishers tended to perceive it as a negative disturbance over fisheries and the environment. Our findings suggest that $C$. sapidus is more common than previously thought in the most of the study area, and it could have reached the levels of a true invasions in the south-eastern Adriatic Sea. This experience demonstrates that online questionnaires can be appropriate tools to effectively engage stakeholders in alien species monitoring.
\end{abstract}

Callinectes sapidus | Atlantic blue crab | recreational fishery | online questionnaires | monitoring invasive species | Local Ecological Knowledge

Correspondence: jacopo.cerri@isprambiente.it

CAUTION

The following manuscript is a preprint: it has been published also on Marine Pollution Bulletin the 11th of May 2020, see https://doi.org/10.1016/j.marpolbul.2020.111209.

\section{Introduction}

Biological invasions are an increasing driver of change for European marine ecosystems (Streftaris et al., 2005; EEA, 2007). As most of them occur due to anthropogenic vectors and impact negatively the recipient ecosystems, they have been defined as a form of "biological pollution", (Boudouresque and Verlaque, 2002; Elliott, 2003), which occupy the first positions on the environmental management agenda.

The abundances and impacts of Invasive Alien Species (IAS) are particularly pronounced in the Mediterranean Sea, one of the world's most invaded marine regions (Edelist et al., 2013). In the last Strategic Plan for Biodiversity (2011-2020),
Target 9 of the Aichi Biodiversity Targets states that, by 2020, IAS must be identified and prioritized, with measures being enforced to manage introduction pathways and their establishment. According to Article 11 of the new European Regulation on invasive species (EU n. 1143/2012), Member States have to carry out a comprehensive analysis of introduction pathways in their territories and a geographical prioritization based on control needs. This approach will assist in the identification of key recipient regions of introduction, which in turn will make the prevention, control and eradication of early biological invasions easier and more effective (Genovesi, 2005).

Unfortunately, these ambitious goals do not account for the increasing number of introductions, their rapid geographical spread, as well as their spatial and ecological dimensions. To date, about 1,000 multicellular non-indigenous-species (NIS) have been introduced in the Mediterranean Sea (Zenetos et al., 2017) and the increasing difficulties of tracking massive invasion (Bonanno and Orlando-Bonaca, 2019; Mazaris and Katsanevakis, 2018) is limiting the implementation of effective adaptation and mitigation policies (Galil et al., 2018).

Conventional ways of surveying the occurrence of NIS and other potentially harmful aquatic organisms have clear limits to provide information on the large geographical scale, especially during the early stages of invasion, when species are typically rare and difficult to detect. Indeed, these surveys can be expensive, time-consuming and of limited efficacy compared to the speed and magnitude of marine bioinvasions (Ojaveer et al., 2018). For example, fishery and port surveys can be barely effective in detecting all the new arrivals (e.g. Azzurro et al., 2019a) and environmental DNA, although promising (Zaiko et al., 2018), is still far from showing adequate standards for its large-scale application in marine environments (Ficetola et al., 2008; Deiner et al., 2017). Therefore, the importance of complementary detec- 
tion strategies has been stressed at both scientific and political levels (Hulme, 2009; Olenin et al., 2011, 2016), and the collaboration with local stakeholders is particularly encouraged (e.g. Crall et al., 2010). These alternative methods can be used to improve our ability of tracking the arrival and subsequent spread of NIS, reducing detection lags (sensu Azzurro et al., 2016) and providing an improved basis for environmental management and decision making. Recent surveys with experienced fishermen demonstrated the possibility of applying these approaches over the large geographical scale (Azzurro et al., 2019) and participatory strategies are receiving an increasing interest in marine bio-invasion research (Poursanidis and Zenetos, 2013; Scyphers et al., 2014).

Certainly, our outcomes can be variable according to the methods used and the stakeholders we decide to involve. For example, most Local Ecological Knowledge (LEK) studies focus on experts, who are generally interviewed with in-depth methods (e.g. face-to-face interviews: Azzurro et al., 2011, 2019b; Maynou et al., 2011), while most citizen science studies extract, sieve and process information from laypeople, through data mining or dedicated apps (Hochachka et al., 2010). These two approaches treat expertise in radically different ways, with tradeoffs in data quantity and quality. Here we accessed the knowledge of recreational fishers, a particular group of sea users, which is familiar with internet and social media (Giovos et al., 2018) and can be recruited for online surveys with minimum efforts and costs (Banha et al., 2015; Martin et al., 2012; Venturelli et al., 2017). So far, online questionnaires, have been extensively adopted in freshwater ecosystems, to investigate public perception of IAS (Nanayakkara et al., 2018) biosecurity practices (Sharp et al., 2017), or invasion pathways (Cerri et al., 2018). However, to the best of our knowledge, their application to IAS monitoring has been nearly inexistent, both in freshwater and in marine environments (Sbragaglia et al., 2019).

In this study, we questioned recreational fishers about a conspicuous alien crustacean, which has the characteristics to capture people's attention and be easily remembered by the respondents: the Atlantic blue crab Callinectes sapidus (Rathbun, 1986). The Atlantic blue crab is a shelf-estuarine species originally distributed in the Eastern coasts of North America, which was introduced in Europe through ballast waters (Bouvier, 1901; Mancinelli et al., 2017a), where it progressively expanded from the Atlantic area, to the Mediterranean and the Black Seas (Mancinelli et al. 2017b; Suaria et al., 2017). Despite local evidences highlighting competitive interactions with native species (Gennaio et al., 2006; Mancinelli et al., 2013) and impacts on smallscale fisheries (Fuentes et al., 2019; Kampouris et al., 2019; Nehring, 2011; Perdikaris et al., 2016; Ventura et al., 2018), the ecological and economic consequences of this invasion have been poorly assessed and our understanding of the species distribution is largely limited to occasional observations (Mancinelli et al., 2017c.; Suaria et al., 2017). Here we engaged a large number of recreational fishers over the Tyrrhenian, Ligurian, Ionian and Adriatic Seas, aiming at

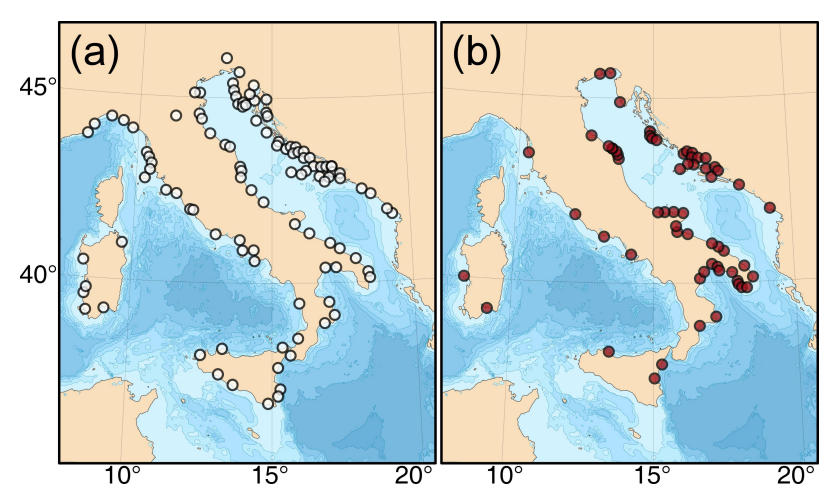

Fig. 1. a) Geographic distribution of on-line respondents $(n=797)$; b) geographical distribution of the recorded observations of C. sapidus $(n=88)$.

investigating i) the geographical distribution of $C$. sapidus in Italy, Croatia and Montenegro; ii) its perceived abundance and trend; iii) the perceived impacts. We finally estimated how well the information provided by these respondents aligned with the knowledge available from the existing literature.

\section{Methods}

Questionnaire administration. Data were extracted from information gathered through an online survey implemented on Google Forms (https://docs.google. $\mathrm{com} /$ forms), which circulated among Italian, Croatian and Montenegrin recreational fishers during the period June 2016-May 2018. Researchers shared the questionnaire link on well-known Facebook groups, oriented towards recreational fishery in the respective countries, and respondents answered anonymously and on a voluntary basis. Researchers ensured confidentiality of the results, to respect respondents' privacy and to minimize response bias.

The questionnaire took approximately 15-20 minutes to be completed and it was structured into four different sections. The first section asked respondents to provide their personal details (sex, age, geographic provenience) and whether they had ever observed some non-native or thermophilic species, including $C$. sapidus. In case of a positive answer to this latter question, respondents completed a second section, asking them about the perceived temporal trend in species abundance and the current abundance of each species in their fishing area. In the last section, respondents expressed their beliefs about the environmental and economic impacts of each species. The questionnaire presented five target species, but in this study we analyzed data about $C$. sapidus only and retained only those observations where respondents specified the location where they had observed C. sapidus.

The same questionnaire was administered in Italian and Croatian languages, though the Italian version presented an additional question (to rate the species as "decreasing", "stable or fluctuating" or "increasing", over the last 10 years), which was absent from Croatian questionnaires. Therefore, we could only measure perceived trends in abundance from Italian respondents. We collected answers from Montenegrin respondents, who noticed the questionnaire on Croatian websites and therefore answered to the Croatian version. 
Data analysis. We grouped the four seas from where respondents came from (Tyrrhenian, Ligurian, Adriatic, Ionian) in two sectors: the Tyrrhenian/Ligurian and the Adriatic/Ionian. We visually tested whether the geographical distribution of our records matched with existing literature about the distribution of the species in the three countries (Castriota et al. 2012, Dulčić et al. 2010, 2011; Mancinelli et al. 2017b; Onofri et al. 2011; Piras et al., 2019; Suaria et al., 2017; Tutman et al. 2017). We measured the relative frequency of the perceived trends of $C$. sapidus, over the last 10 years, for Italian respondents. Then, we compared the number of respondents who declared to have observed the species in the Tyrrhenian/Ligurian and in the Adriatic/Ionian sector, through Fisher's exact test. Finally, we calculated the relative frequencies of perceived environmental and economic impacts of $C$. sapidus and we modeled how the probability of perceived negative impacts was associated to the perceived abundance of $C$. sapidus, through a logistic regression. Mapping and statistical analyses were carried out with the statistical software R (R Core Team, 2019). In the logistic regression we checked for model residuals, as well as for the assumption of linearity and for the occurrence of influential values. A reproducible software code is available in the Supplementary Information.

\section{Results}

Sample characterization. We retained a total of $787 \mathrm{com}-$ pleted questionnaires from Italy $(82.8 \%)$, Croatia (16.7\%) and Montenegro (0.5\%). For sake of simplicity we will refer from now on to respondents from Croatia and Montenegro as "Croatian respondents". The sample was composed almost entirely by male respondents (97.2\%). Most respondents were between 20 and 50 years old (unspecified age $=$ $2.9 \%$; $<20$ years $=7.7 \%, 21-30$ years $=25.8 \%, 31-40$ years $=27.7 \%, 41-50$ years $=22.2 \%, 51-60$ years $=$ $10.2 \%, 61-70$ years $=3.3 \%,>70$ years $=0.1 \%)$ and started fishing after 1990 (unspecified $=2.3 \% ; 1960=5.7 \% ; 1970$ $=10.7 \% ; 1980=19.9 \% ; 1990=20.9 \% ; 2000=19.9 \%$; $2010 \mathrm{~s}=20.5 \%)$. Nearly half respondents practiced recreational spearfishing only $(51.4 \%)$ and fewer of them were anglers $(18.2 \%)$ or practiced both $(29.8 \%)$. Among Croatian respondents, some of them also practiced longline fishing $(22.1 \%)$ or used fishing pots $(8.8 \%)$. Among Italian respondents, roughly half of them came from the Tyrrhenian Sea $(50.6 \%)$, while fewer of them were from the Adriatic (32.6\%), the Ionian (13.3\%) and the Ligurian Seas (8.4\%). A complete overview about the survey structure is available on the online version of the dataset (http://doi.org/ 10.5281 / zenodo.3588353). The spatial distribution of respondents is available in Fig. 1.

Records of $\boldsymbol{C}$. sapidus. Overall, only 88 respondents reported to have observed $C$. sapidus. Most records came from the Adriatic Sea, both from the Italian $(n=32)$ and from the Croatian and Montenegrin coasts $(n=24)$, as well as from the Ionian coast $(n=24)$, while only 8 observations were from the Tyrrhenian Sea. A complete list of the georeferenced records

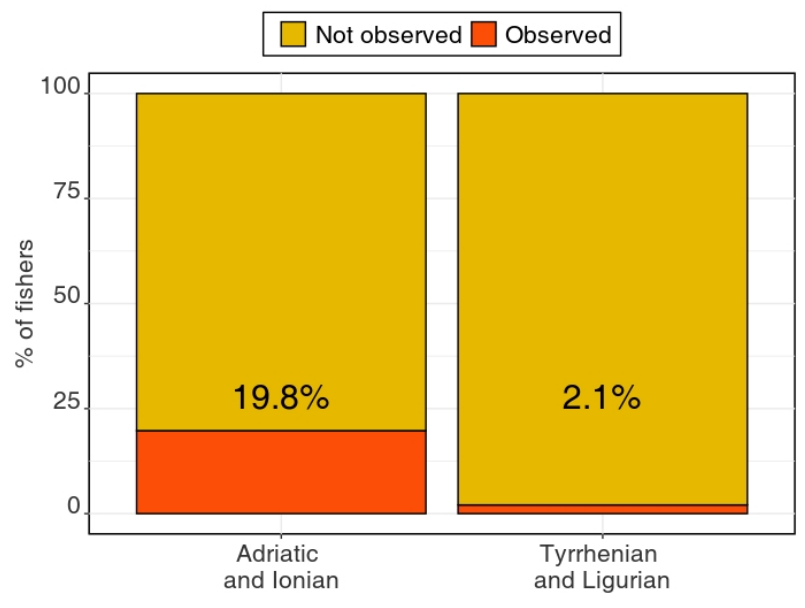

Fig. 2. Proportion of respondents who observed C. sapidus in the Adriatic/lonian $(n=80)$ and Thyrrenian/Ligurian Sea $(n=8)$.

of $C$. sapidus is available in the Supplementary Information. The proportion of respondents who declared to have observed the species was higher in the Adriatic/Ionian sector (19.8\%) than in the Tyrrhenian/Ligurian one (2.1\%) (Fig.2; Fisher's exact test: $\mathrm{p}<0.01)$. On the Adriatic/Ionian sector, we noticed a hotspot of records from the Apulia region, notably around the Gargano peninsula and in the Gulf of Taranto (Fig. 1). Most respondents were between 20 and 50 years old (unspecified age $=5.6 \% ;<20$ years $=6.8 \%, 21-30$ years $=$ $28.4 \%, 31-40$ years $=27.3 \%, 41-50$ years $=21.6 \%, 51$ -60 years $=6.8 \%, 61-70$ years $=3.4 \%,>70$ years $=0 \%)$ and started fishing after 1980 (unspecified $=2.27 \%, 1960=$ $6.8 \% ; 1970=12.5 \% ; 1980=20.5 \% ; 1990=14.7 \% ; 2000=$ $20.5 \% ; 2010 \mathrm{~s}=22.7 \%)$. Most of those who reported to have observed the species were spearfishers $(34.1 \%)$, while fewer were anglers $(23.9 \%)$ or practiced both spearfishing and angling $(39.8 \%)$.

\section{Population trend, perceived abundance and first ob-} servations. When analyzing the perceived abundance trends of $C$. sapidus, we noticed that most Italian respondents deemed the species to be "stable or fluctuating" $(43.5 \%)$ or "increasing" (40.3\%). Only a minority of Italian respondents believed $C$. sapidus to have decreased $(16.1 \%)$ over the last 10 years. C. sapidus also seemed to be generally more abundant in the Adriatic/Ionian area, where $25.4 \%$ of respondents rated the species from "Common" to "Dominant", than in the Tyrrhenian one, where species was almost entirely rated as "Rare" or "Occasional" (87.5\%). The high values of perceived abundance of $C$. sapidus in the Adriatic/Ionian sector depended almost in total from the hotspot in the Apulia region. We also recorded two observations ranking the species as "Abundant" on the Calabrian coast $(\mathrm{n}=1)$ and "Dominant" in Eastern Sicily $(\mathrm{n}=1)$. These observations were outliers. On the Calabrian coast, the only other record, from Crotone (approx $43 \mathrm{~km}$ Northern of Catanzaro) ranked C. sapidus as "rare". In Sicily, the other two records from Palermo and Giardini-Naxos ranked C. sapidus abundance as "rare" or "absent". 


\begin{tabular}{|c|c|c|c|}
\hline \multicolumn{4}{|c|}{ Negative impacts over the environment } \\
\hline Predictors & Odds-ratios & $95 \% \mathrm{CI}$ & $\mathrm{p}$-value \\
\hline Intercept & 0.21 & $0.06-0.73$ & 0.014 \\
\hline Abundance & 1.43 & $0.98-2.08$ & 0.066 \\
\hline \multicolumn{2}{|c|}{ N.observations $=79$} & \multicolumn{2}{|c|}{$\mathrm{R}^{2}=0.047$} \\
\hline \multicolumn{4}{|c|}{ Negative impacts over fisheries } \\
\hline Predictors & Odds-ratios & $95 \% \mathrm{CI}$ & p-value \\
\hline Intercept & 0.09 & $0.02-0.35$ & 0.001 \\
\hline Abundance & 1.65 & $1.10-2.48$ & 0.016 \\
\hline N.observ & $\mathrm{ns}=80$ & \multicolumn{2}{|c|}{$\mathrm{R}^{2}=0.084$} \\
\hline
\end{tabular}

Table 1. Output from the logistic regression: effect of perceived abundance of C. sapidus over predicted probabilities of believing in its negative impact over the environment or over fisheries.

Perception of impacts. When considering respondents' beliefs about the impacts of $C$. sapidus, most respondents did not have clear ideas about the potential environmental consequences of the species (Italy $=52.4 \%$, Croatia and Montenegro $=50.0 \%$ ), nor about its potential consequences over fisheries $($ Italy $=52.4 \%$, Croatia and Montenegro $=47.8 \%)$. Fewer respondents believed $C$. sapidus capable to negatively affect the environment (Italy $=31.7 \%$, Croatia and Montenegro $=50.0 \%$ ), and the proportion was even lower for fisheries $($ Italy $=22.2 \%$, Croatia and Montenegro $=47.8 \%$ ). Finally, only a minority of respondents was convinced that the presence of $C$. sapidus could benefit the environment (Italy $=15.8 \%$, Croatia and Montenegro $=0.0 \%$ ) or fisheries (Italy $=25.4 \%$, Croatia and Montenegro $=4.3 \%$ ). There were no significant differences in perceived impacts between respondents from Italy and respondents from Croatia and Montenegro, as the Fisher's test turned out to be not significant. However, the evaluation of potential environmental impacts was associated with the evaluation of potential impacts over fisheries (Fisher's exact test: $\mathrm{p}<0.01$ ): respondents who believed $C$. sapidus to negatively affect the environment were also prone to believe that it would also negatively affect fisheries. Logistic regression revealed that, as respondents deemed $C$. sapidus to be more and more abundant, they also tended to believe it to threaten both fisheries and the environment (Table 1, Fig.3).

\section{Discussion}

Our findings show that the knowledge of recreational fishers can be easily accessed, through online questionnaires, to reconstruct the distribution of a conspicuous IAS over a large geographical scale. Citizen-generated sightings provided geo-referenced observations, which enriched our knowledge on the presence of $C$. sapidus along the Mediterranean coasts. So far, online questionnaires have been under-employed in marine bioinvasion research (Scyphers et al., 2015), nevertheless our findings demonstrate that these tools can be effective systems for investigating the distribution of these species and for gathering key information about stakeholder's perceptions. It is worth noticing that online questionnaires enabled us to collect all this valuable information with limited efforts and costs, although our sample of respondents was considerable and distributed along the coastlines of three dif-

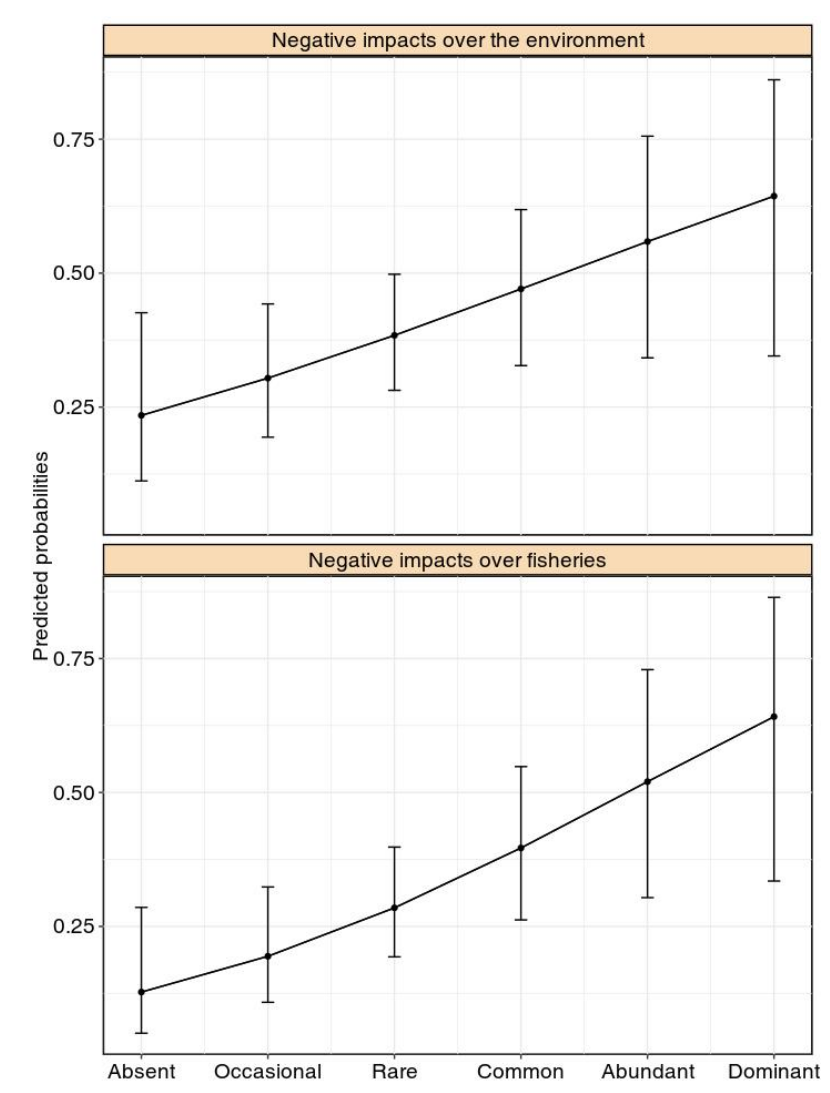

Fig. 3. Perceived impacts of C. sapidus over the marine environment (upper panel) and over fisheries (lower panel): predicted probabilities of a negative impact for different levels of perceived abundances.

ferent countries.

Overall, our findings contribute implementing the existing knowledge about the distribution of $C$. sapidus in the Mediterranean Sea (Castriota et al. 2012; Dulčić et al. 2010, 2011; Mancinelli et al. 2017b; Onofri et al. 2011; Piras et al., 2019; Suaria et al., 2017; Tutman et al. 2017). In the most recent revisions, both Mancinelli et al. (2017b) and Suaria et al. (2017) indicated that in Italy, C. sapidus is more common in the Adriatic than in the Tyrrhenian Sea, where the species was reported from the northernmost sectors of the Tyrrhenian Sea. Our survey also allowed to record observations from the Central and Southern sectors of the Tyrrhenian Seas (Latium region, Naples, Tyrrhenian Calabria and Sicily), were the species was not reported before. This could indicate that $C$. sapidus might be more widespread along the Italian coasts than previously hypothesized. Our findings also remark that $C$. sapidus is currently widespread in Croatia and Montenegro.

The perceived trends of $C$. sapidus seem to indicate that the species is still undergoing the early stages of its invasion in most of the study area. Two points support this conclusion. First, only 88 of 787 respondents reported to have observed C. sapidus, although the species is relatively easy to observe and to identify. Moreover, most respondents were uncertain about the temporal increase of the species over the last 10 years, deeming it to be "stable of fluctuating" and most of them perceived it as "rare" or "occasional". 
Taken together, these findings indicate that, at the time of the survey, $C$. sapidus has not attained the levels of a true invasion in most of the study area, as IAS are usually noticed by stakeholders after becoming abundant and widespread (Azzurro et al., 2016; Mehta et al., 2007). Nevertheless, our findings demonstrate that the species is more widespread and common than previously thought. This conclusion is also supported by a number of additional observations spontaneously posted on social networks, such as the facebook group 'Oddfish' (https : / / www. facebook. com/ groups/1714585748824288/search/ ?query= Callinectes\&epa=SEARCH_BOX), which would testify the occurrence of the species in a number of coastal sites (see Taranto, Bari, Trapani, Latina, Comacchio, Salento, Calabrian coasts in Italy) with possible hotspots in a number of estuaries and lagoons (such as Lesina Lagoon, salt lake of Fusaro, mouth of river Alento, Chioggia, Mouth of river Brenta, Cabras lagoon in Italy). Finally, our online survey demonstrates that $C$. sapidus is generally more abundant in the Adriatic and Ionian Seas, where it was observed by a higher proportion of respondents (Fig. 2). We also noted that a single observation from Catania, on the Ionian coast of Sicily could be attributed to a possible confusion with a morphologically similar invasive portunid, Portunus segnis (Forskål, 1775), originally described as Portunus pelagicus (Linnaeus, 1758), whose occurrence was not contemplated by our online questionnaire. Indeed, during the formulation of our online questionnaires, in 2016, we assumed that $C$. sapidus, had no similar species to be confounded with, since it was the only conspicuous and of large-sized blue crab established in the study area. Yet, to our best knowledge, $P$. segnis has been recorded only once in Italy (Crocetta et al., 2006) but preceding a rapid spread over the Tunisian coasts (Annabi et al., 2018; Bdioui, 2016; Béjaoui et al., 2019; Hamida et al., 2019) it could have reached the eastern Sicily coasts and being locally fished (Deidun and Sciberras, 2016; V. Di Martino pers. comm.) with a new recent record from Lampedusa island, Sicily Strait (ISPRA personal communication). Nevertheless, according to our best knowledge, possible misidentification between the two species could have only concerned two observations in eastern Sicily, without representing any significant bias to our study.

Certainly, considering the potential ecological and economic impacts of both $C$. sapidus and P. segnis, their occurrence deserve to be closely monitored in the near future. We also encourage modeling studies, especially habitat suitability models (e.g. D'Amen and Azzurro, 2019) for identifying those coastal areas, such as estuaries and lagoons, which are more vulnerable to the blue crab invasions. This is an extremely important information, given its capacity to alter food webs and to negatively interact with human activities, particularly with small scale fishing (Mancinelli et al. 2017a).

Results about the perceived impacts of $C$. sapidus and its abundance also deserve some further considerations. Indeed, recreational fishers represent expert actors to be involved in monitoring and management strategies for IAS (Nanayakkara et al., 2018) and their perceptions represent an important first step to evaluate the socio-economic impacts of IAS and the chronology of their invasion. During the early stages of a biological invasion, stakeholders do not have clear ideas of the impacts of IAS over native species and ecosystems (Nuñez et al., 2018). Then, once these impacts emerge, they become salient and concur, altogether with the economic importance gained by the IAS, in shaping public attitudes (Clavero et al., 2016; Crowley et al., 2017; Shackleton et al., 2019). Our findings indicate that recreational fishers have uncertain beliefs about the impacts of the blue crab on fisheries and the environment, despite $C$. sapidus can cause major ecological and economic consequences (Fuentes et al., 2019; Kampouris et al., 2019; Mancinelli et al., 2017a; Nehring, 2011; Perdikaris et al., 2016; Ventura et al., 2018). As we already mentioned, this uncertainty is likely to indicate an early stage of invasion by $\mathrm{C}$. sapidus, where the species is not yet perceived as economically important, neither in a positive, nor in a negative way (Clavero et al., 2016). Interestingly, we observed a stable relationship between abundance and beliefs: the more $C$. sapidus was considered to be common, the more fishers tended to believe in its negative impacts over fisheries and the environment, as expected by the abundanceperception relationships described by Clavero et al. (2016). Future studies could clarify how this tendency is emerging, disentangling direct observations (some fishers might already noticing the predatory impacts of $C$. sapidus) from cultural transmission (e.g. through online forums or social networks, Shiffman et al., 2017).

\section{Conclusions}

This study shows how policymakers and conservationists can leverage on online questionnaires, administered to recreational fishermen, to map biological pollution and to reconstruct invasion dynamics of IAS.

Online questionnaires can provide valuable information on current biological invasions, which could complement traditional forms of data collection, like ecological surveys (Sharp et al., 2011) but a key aspect of this approach is to employ conspicuous and easy-to-recognize species. Our study also shows that recreational fishers are relatively easy to recruit through online questionnaires and their observations might serve the needs of bio-invasion research. Although structured questionnaires are a relatively "static" tool for eliciting beliefs, leaving no room for expert deliberation, they are a cost-effective approach, which sounds particularly promising for monitoring rapid phenomena of global change, like biological invasions.

We also believe that large-scale surveys based on online questionnaires might be important as a tool to raise stakeholders' awareness about biological invasions. Even if respondents did not receive any in-depth information about this topic, our study provided the first opportunity for many of them to be invited to consider $C$. sapidus and its potential environmental and economic impacts. Providing fishermen with this novel information might be potentially very important to further engage them in monitoring and management actions. This is particularly important for edible species such as the blue crab, 
whose spread can be counteracted by promoting their responsible commercial exploitation (Nuñez et al., 2012). Raising environmental awareness will also limit the possibility of intentional releases and illegal harvesting activities (Mancinelli et al., 2017c), which can contribute to a further spread of the species through the inappropriate management of propagules. This scenario has already been observed for other invasive alien species turned into important commercial products: for example, the Manila clam Ruditapes philippinarum (Adams Reeve, 1850), which has been intentionally introduced in Europe during the '70s-'90s decades (Breda et al., 2017; Chiesa et al., 2017, 2018; Sfriso et al., 2018).

Giving the increasing magnitude of Mediterranean bioinvasions, online surveys could be valuable approach to improve early detection and population monitoring, providing complementary knowledge at the low cost. These surveys may also promote public awareness, education and best practices, supporting management activities and adaptation, as for instance promoting the recreational and/or commercial exploitation of the Atlantic blue crab.

\section{ACKNOWLEDGEMENTS}

This study was funded in part by the Croatian Science Foundation (HRZZ), under the project IP-2016-06-5251. We thank to Mr. P. Ugarković and V. Sbragaglia for their help in disseminating the questionnaires and to Mrs. Zorana Frkic for the Croatian translation.

\section{References}

Annabi, A., Bardelli, R., Vizzini, S., Mancinelli, G. (2018). Baseline assessment of heavy metals content and trophic position of the invasive blue swimming crab Portunus segnis (Forskål, 1775) in the Gulf of Gabès (Tunisia). Marine pollution bulletin, 136, 454-463.

Azzurro, E., Bolognini, L., Dragičević, B., Drakulović, D., Dulčić, J., Fanelli, E., ... Marković, O. (2019). Detecting the occurrence of indigenous and non-indigenous megafauna through fishermen knowledge: A complementary tool to coastal and port surveys. Marine pollution bulletin, 147, 229-236.

Azzurro, E., Sbragaglia, V., Cerri, J., Bariche, M., Bolognini, L., Ben Souissi, J., ... Ghanem, R. (2019). Climate change, biological invasions, and the shifting distribution of Mediterranean fishes: A large-scale survey based on local ecological knowledge. Global change biology.

Azzurro, E., Moschella, P., Maynou, F. (2011). Tracking signals of change in Mediterranean fish diversity based on local ecological knowledge. PLoS One, 6(9), e24885.

Azzurro, E., Maynou, F., Belmaker, J., Golani, D., Crooks, J. A. (2016). Lag times in Lessepsian fish invasion. Biological invasions, 18(10), 27612772.

Banha, F., Ilhéu, M., Anastácio, P. M. (2015). Angling web forums as an additional tool for detection of new fish introductions: the first record of Perca fluviatilis in continental Portugal. Knowledge and Management of Aquatic Ecosystems, (416), 03.

Bdioui, M. (2016). Premier signalement du crabe bleu Portunus segnis (Forskål, 1775) dans le sud du Golfe de Hammamet (Centre-Est de la Tunisie). Bull. Inst. Natn. Scien. Tech. Mer de Salammbô, 43.

Béjaoui, B., Ben Ismail, S., Othmani, A., Ben Abdallah-Ben Hadj Hamida, O., Chevalier, C., Feki-Sahnoun, W., ... Diaz, F. (2019). Synthesis review of the Gulf of Gabes (eastern Mediterranean Sea, Tunisia): Morphological, climatic, physical oceanographic, biogeochemical and fisheries features. Estuarine, Coastal and Shelf Science, 219, 395-408.

Bonanno, G., Orlando-Bonaca, M. (2019). Non-indigenous marine species in the Mediterranean Sea-Myth and reality. Environmental Science Policy, 96, 123-131.

Boudouresque, C. F., Verlaque, M. (2002). Biological pollution in the Mediterranean Sea: invasive versus introduced macrophytes. Marine pollution bulletin, 44(1), 32-38.
Bouvier, E.L., 1901. Sur un Callinectes sapidus M. Rathbun trouvue a Rocheford. Bull.Du. Mus. d'Histoire Nat. Paris 7, 16-17.

Breda S., Chiesa S., Freitas R., Figueira E., Becherini F., Gobbo L., Soares A.M.V.M., Argese E., 2018. Biogeochemical dynamics and bioaccumulation processes in Manila clam: Implications for biodiversity and ecosystem services in the Ria de Aveiro Lagoon. Estuarine Coastal and Shelf Science 209: 136-148.

Castriota, L., Andaloro, F., Costantini, R., De Ascentiis, A. (2012). First record of the Atlantic crab Callinectes sapidus Rathbun, 1896 (Crustacea: Brachyura: Portunidae) in Abruzzi waters, central Adriatic Sea. Acta Adriatica, 53(3).

Clavero, M. (2016). Species substitutions driven by anthropogenic positive feedbacks: Spanish crayfish species as a case study. Biological conservation, 193, 80-85.

Cerri, J., Ciappelli, A., Lenuzza, A., Zaccaroni, M., Nocita, A. (2018). Recreational angling as a vector of freshwater invasions in Central Italy: perceptions and prevalence of illegal fish restocking. Knowledge Management of Aquatic Ecosystems, (419), 38.

Chiesa S., Lucentini L., Freitas R., Nonnis Marzano F., Breda S., Figueira E., Caill-Milly N., Herbert R., Soares A.M.V.M., Argese E. 2017. A history of invasion: COI phylogeny of Manila clam Ruditapes philippinarum in Europe. Fisheries Research, 186, 25-35.

Chiesa S., Chainho P., Almeida A., Figueira E., Soares A.M.V.M., Freitas, 2018. Metals and As content in sediments and Manila clam Ruditapes philippinarum in the Tagus estuary (Portugal): Impacts and risk for human consumption. Marine Pollution Bulletin, 126: 281-292.

Crall, A. W., Newman, G. J., Jarnevich, C. S., Stohlgren, T. J., Waller, D. M., Graham, J. (2010). Improving and integrating data on invasive species collected by citizen scientists. Biological Invasions, 12(10), 3419-3428.

Crocetta, F. (2006). First record of Portunus pelagicus (Linnaeus, 1758)(Decapoda, Brachyura, Portunidae) in the northern Tyrrhenian Sea. Crustaceana-International Journal of Crustacean Research, 79(9), 1145.

Crowley, S. L., Hinchliffe, S., McDonald, R. A. (2017). Conflict in invasive species management. Frontiers in Ecology and the Environment, 15(3), 133-141.

D'Amen, M., Azzurro, E. (2019). Lessepsian fish invasion in Mediterranean marine protected areas: a risk assessment under climate change scenarios. ICES Journal of Marine Science, 1-10. doi:10.1093/icesjms/fsz207.

Deiner, K,, Bik, H.M., Mächler, E., Seymour, M., Lacoursière-Roussel, A., Altermatt, F., Creer, S., Bista, I., Lodge, D.M., de Vere, N., Pfrender, M.E., Bernatchez, L. (2017) Environmental DNA metabarcoding: Transforming how we survey animal and plant communities. Molecular Ecology, 26, 5872-5895.

Deidum, A., Sciberras, A. (2016). A further record of the blue swimmer crab Portunus segnis Forskal, 1775 (Decapoda: Brachyura: Portunidae) from the Maltese Islands (Central Mediterranean). BioInvasion Records, 5, 43-6.

Dulčić, J., Dragicevic, B. (2010). New record of the blue crab, Callinectes sapidus Rathbun, 1896,(Decapoda: Brachyura) in the Adriatic Sea. In Annales: Series Historia Naturalis (Vol. 20, No. 1, p. 23). Scientific and Research Center of the Republic of Slovenia.

Dulčić, J., Tutman, P., Matić-Skoko, S., Glamuzina, B. (2011). Six years from first record to population establishment: the case of the blue crab, Callinectes sapidus Rathbun, 1896 (Brachyura, Portunidae) in the Neretva River delta (South-eastern Adriatic Sea, Croatia). Crustaceana (Leiden), 84(10), 1211

Edelist D, Rilov G, Golani D, Carlton JT, Spanier E (2013) Restructuring the Sea: profound shifts in the world's most invaded marine ecosystem. Diversity and Distributions, 19, 69-77.

EEA, 2007. Europe's environment - The fourth assessment. State of the environment, European Environment Agency, Report No 1/2007. Office for Official publications of the European Community, Luxembourg: http://www.eea.europa.eu/publications/state $f_{e}$ nvironment $_{r}$ eport $_{2} 007_{1}$

Elliott, M. (2003). Biological pollutants and biological pollution-an increasing cause for concern. Marine Pollution Bulletin, 46(3), 275-280.

Ficetola, G.F,, Miaud, C,, Pompanon, F,, Taberlet, P. (2008) Species detection using environmental DNA from water samples. Biology Letters, 4, 423-425.

Fuentes, M. A., Torrent, L., Barrera, S., Boix, D. (2019). Rapid invasion of the American blue crab Callinectes sapidus Rathbun, 1896 in the NorthEast of the Iberian Peninsula. BioInvasions Records, 8(1), 113-118. 
Galil B, Marchini A, Occhipinti-Ambrogi A, Ojaveer H., 2017. The enlargement of the Suez Canal Erythraean introductions and management challenges. Management of Biological Invasions, 8, Issue 2: 141-152.

Gennaio, R., Scordella, G., Pastore, M. (2006). Occurrence of blue crab Callinectes sapidus (Rathbun, 1986, Crustacea, Brachyura), in the Ugento ponds area (Lecce, Italy). Thalassia salentina, 29, 29-39.

Genovesi, P. (2005). Eradications of invasive alien species in Europe: a review. Biological invasions, 7(1), 127-133.

Giovos, I., Keramidas, I., Antoniou, C., Deidun, A., Font, T., Kleitou, P., ... Moutopoulos, D. K. (2018). Identifying recreational fisheries in the Mediterranean Sea through social media. Fisheries Management and Ecology, 25(4), 287-295.

Hamida, O. B. A. B. H., Hamida, N. B. H., Ammar, R., Chaouch, H., Missaoui, H. (2019). Feeding habits of the swimming blue crab Portunus segnis (Forskål, 1775)(Brachyura: Portunidae) in the Mediterranean. Journal of the Marine Biological Association of the United Kingdom, 1-9.

Hochachka, W. M., Fink, D., Hutchinson, R. A., Sheldon, D., Wong, W. K., Kelling, S. (2012). Data-intensive science applied to broad-scale citizen science. Trends in ecology evolution, 27(2), 130-137.

Hulme, P. E. (2009). Trade, transport and trouble: managing invasive species pathways in an era of globalization. Journal of applied ecology, 46(1), 10-18.

Kampouris, T. E., Porter, J. S., Sanderson, W. G. (2019). Callinectes sapidus Rathbun, 1896 (Brachyura: Portunidae): An assessment on its diet and foraging behaviour, Thermaikos Gulf, NW Aegean Sea, Greece: Evidence for ecological and economic impacts. Crustacean Research, 48, 2337.

Mancinelli, G., Carrozzo, L., Marini, G., Costantini, M.L., Rossi, L., Pinna, M., 2013. Occurrence of the Atlantic blue crab Callinectes sapidus (Decapoda, Brachyura, Portunidae) in two Mediterranean coastal habitats: temporary visitor or permanent resident? Estuarine, Coastal and Shelf Science $135,46-56$.

Mancinelli G., Guerra M.T., Alujević K., Raho D., Zotti M., Vizzin S., 2017a Trophic flexibility of the Atlantic blue crab Callinectes sapidus in invaded coastal systems of the Apulia region (SE Italy): A stable isotope analysis. Estuarine, Coastal and Shelf Science 198: 421-431.

Mancinelli, G., Chainho, P., Cilenti, L., Falco, S., Kapiris, K., Katselis, G., Ribeiro, F. (2017). The Atlantic blue crab Callinectes sapidus in southern European coastal waters: Distribution, impact and prospective invasion management strategies. Marine pollution bulletin, 119(1), 5-11.

Mancinelli, G., Chainho, P., Cilenti, L., Falco, S., Kapiris, K., Katselis, G., Ribeiro, F., 2017c. On the Atlantic blue crab (Callinectes sapidus Rathbun 1896) in southern European coastal waters: Time to turn a threat into a resource? Fisheries Research, 194, 1-8.

Martin, D. R., Pracheil, B. M., DeBoer, J. A., Wilde, G. R., Pope, K. L. (2012). Using the Internet to understand angler behavior in the information age. Fisheries, 37(10), 458-463.

Maynou, F., Sbrana, M., Sartor, P., Maravelias, C., Kavadas, S., Damalas, D., ... Osio, G. (2011). Estimating trends of population decline in long-lived marine species in the Mediterranean Sea based on fishers' perceptions. PLoS One, 6(7), e21818.

Mazaris, A. D., Katsanevakis, S. (2018). The threat of biological invasions is under-represented in the marine protected areas of the European Natura 2000 network. Biological conservation, 225, 208-212.

Mehta, S. V., Haight, R. G., Homans, F. R., Polasky, S., Venette, R. C. (2007). Optimal detection and control strategies for invasive species management. Ecological Economics, 61(2-3), 237-245.

Nanayakkara L., Jurdi-Hage R., Leavitt P.R., Wissel B., 2018. In lakes but not in minds: stakeholder knowledge of invasive species in prairie lakes. Biological Invasions 20:633-652.

Nehring, S., 2011. Invasion history and success of the american blue crab Callinectes sapidus in European and adjacent waters. In: Galil, B.S., Clark, P.F., Carlton, J.T.(Eds.), In the Wrong Place - Alien Marine Crustaceans: Distribution, Biology and Impacts. Invading Nature - Springer Series in Invasion Ecology. Springer, Netherlands, pp. 607-624.

Nuñez, M. A., Dimarco, R. D., Simberloff, D. (2018). Why some exotic species are deeply integrated into local cultures while others are reviled. In From Biocultural Homogenization to Biocultural Conservation (pp. 219231). Springer.

Nuñez, M. A., Kuebbing, S., Dimarco, R. D., Simberloff, D. (2012). Invasive species: to eat or not to eat, that is the question. Conservation Letters, 5(5), 334-341.
Ojaveer, H., Galil, B. S., Carlton, J. T., Alleway, H., Goulletquer, P., Lehtiniemi, M., ... Ruiz, G. M. (2018). Historical baselines in marine bioinvasions: Implications for policy and management. PloS one, 13(8), e0202383.

Olenin, S., Elliott, M., Bysveen, I., Culverhouse, P. F., Daunys, D., Dubelaar, G. B., ... Mézeth, K. B. (2011). Recommendations on methods for the detection and control of biological pollution in marine coastal waters. $\mathrm{Ma}$ rine Pollution Bulletin, 62(12), 2598-2604.

Olenin, S., Narščius, A., Gollasch, S., Lehtiniemi, M., Marchini, A., Minchin, D., Srèbalienè, G. (2016). New arrivals: an indicator for nonindigenous species introductions at different geographical scales. Frontiers in marine science, 3, 208.

Onofri, V., Dulčić, J., Conides, A., Matić-Skoko, S., Glamuzina, B. (2008). The occurrence of the blue crab, Callinectes sapidus Rathbun, 1896 (Decapoda, Brachyura, Portunidae) in the eastern Adriatic (Croatian coast). Crustaceana, 403-409.

Perdikaris, C., Konstantinidis, E., Gouva, E., Ergolavou, A., Klaoudatos, D., Nathanailides, C., Paschos, I. (2015). Occurrence of the invasive crab species Callinectes sapidus Rathbun, 1896, in NW Greece. Walailak Journal of Science and Technology (WJST), 13(7), 503-510.

Piras, P., Esposito, G., Meloni, D. (2019). On the occurrence of the blue crab Callinectes sapidus (Rathbun, 1896) in Sardinian coastal habitats (Italy): a present threat or a future resource for the regional fishery sector. BioInvasions Records, 8(1), 134-141.

Poursanidis, D., Zenetos, A. (2013). The role played by citizen scientists in monitoring marine alien species in Greece. Cahiers de Biologie Marine, $54,419-426$.

Scyphers, S. B., Powers, S. P., Akins, J. L., Drymon, J. M., Martin, C. W., Schobernd, Z. H., ... Switzer, T. S. (2015). The role of citizens in detecting and responding to a rapid marine invasion. Conservation Letters, 8(4), 242-250.

Sfriso A.A., Chiesa S., Sfriso A., Buosi A., Gobbo L., Boscolo Gnolo A., Argese E., 2018. Spatial distribution, bioaccumulation profiles and risk for consumption of edible bivalves: a comparison among razor clam, Manila clam and cockles in the Venice Lagoon. Science of the Total Environment, 643: 579-591.

Shackleton, R. T., Richardson, D. M., Shackleton, C. M., Bennett, B., Crowley, S. L., Dehnen-Schmutz, K., ... Marchante, E. (2019). Explaining people's perceptions of invasive alien species: A conceptual framework. Journal of environmental management, 229, 10-26.

Sharp, R. L., Cleckner, L. B., DePillo, S. (2017). The impact of on-site educational outreach on recreational users' perceptions of aquatic invasive species and their management. Environmental Education Research, 23(8), 1200-1210.

Sharp, R. L., Larson, L. R., Green, G. T. (2011). Factors influencing public preferences for invasive alien species management. Biological Conservation, 144(8), 2097-2104.

Shiffman, D. S., Macdonald, C., Ganz, H. Y., Hammerschlag, N. (2017). Fishing practices and representations of shark conservation issues among users of a land-based shark angling online forum. Fisheries research, 196, 13-26.

Sbragaglia, V., Cerri, J., Bolognini, L., Dulčić, J., Grati, F., Dragičević, B., Azzurro, E. (2019). Local ecological knowledge of recreational fishers reveals different meridionalization dynamics of two Mediterranean subregions. Marine Ecology Progress Series. DOI: https://doi.org/10.3354/meps13193.

Streftaris N, Zenetos A, Papathanasiou E, 2005. Globalisation in marine ecosystems: the story of non-indigenous marine species across European seas. Oceanography and marine biology: an annual review, 43: 419- 453.

Suaria G.; Pierucci A., Zanello P.P., Fanelli E., Chiesa S., Azzurro E. (2017). Percnon gibbesi (H. Milne Edwards, 1853) and Callinectes sapidus (Rathbun, 1896) in the Ligurian Sea: two additional invasive species detection made in collaboration with local fishermen. BioInvasions Records 6(2), 147-151.

Tutman, P., Dulčić, J., Dragičević, B. (2017). Occurrence of the Invasive Blue Crab Callinectes sapidus Rathbun, 1896 (Crustacea: Portunidae) in the Adriatic Sea in Croatia.

Ventura, M. P., Salgado, S. Q., de Arenas, J. H. N., Cano, J. V., Mata, P. R., Soriano, J. L. (2018). Predation of the blue crab Callinectes sapidus Rathbun, 1896 on freshwater bivalves (Unionidae Corbiculidae) in eastern Iberian Peninsula. Folia Conchyliologica, 47. 
Venturelli, P. A., Hyder, K., Skov, C. (2017). Angler apps as a source of recreational fisheries data: opportunities, challenges and proposed standards. Fish and Fisheries, 18(3), 578-595.

Zaiko, A., Pochon, X., Garcia-Vazquez, E., Olenin, S., Wood, S. A. (2018). Advantages and limitations of environmental DNA/RNA tools for improved marine biosecurity: management and surveillance of nonindigenous species. Frontiers in Marine Science, 5, 322. 